chowawców. Jednym i drugim (teoretykom i praktykom) lektura ta przybliża kolejne tajniki samotności i wspólnotowości jako wymiarów ludzkiej egzystencji, a jednocześnie najważniejszych wyzwań w dziele wychowania.

Lucyna Dziaczkowska*

\title{
Bibliografia
}

Kubinowski, Dariusz. „Pedagogiczne myślenie humanistyczne jako kategoria metodologiczna". W: Metodologia pedagogiki zorientowanej humanistycznie, red. Dariusz Kubinowski, Marian Nowak, 171-187. Kraków: Oficyna Wydawnicza „Impuls”, 2006.

Wałejko, Małgorzata. Osobno i razem. Personalistyczne wychowania do samotności $i$ wspólnoty. Szczecin: Wydawnictwo Naukowe Uniwersytetu Szczecińskiego, 2016.

\section{Walt Larimore, Barb Larimore, Jej mózg, jego mózg czyli Bóg wie, co robi, Poznań: W drodze, 2016, s. 254.}

DOI: http://dx.doi.org/10.12775/PCh.2017.018

Od czasu wydania w 1989 roku jednej z najważniejszych książek dotyczących różnic pomiędzy mężczyzną a kobietą, czyli Ptci mózgu. O prawdziwej różnicy między mężczyzna a kobieta (oryg. Brain Sex. The Real Difference Between Men and Women), minęło już ponad 25 lat. Od tamtego czasu w społecznym postrzeganiu płci, męskości i kobiecości wydarzyło się sporo, by wspomnieć tylko o zakrojonej na szeroką skalę promocji ideologii gender i związanego z nią ruchu LGB (T,Q itd.), ostatnio przemianowywanego na MOGAI (ang. Marginalized Orientations, Gender identities, And Intersex), gdyż do pierwotnego skrótu LGB dodawano kolejne kategorie, co ostatecznie doprowadziło do skonstruowania tworu literowego LGBTQIAP+ (w języku ang. Lesbian, Gay, Bisexual, Transgender and Two-spirited, Queer and Questioning, Intersex, Asexual, Pansexual and other marginalized orien-

* Dr hab. Lucyna Dziaczkowska, prof. KUL, pracuje w Katedrze Pedagogiki Porównawczej i Filozofii Wychowania w Instytucie Pedagogiki Katolickiego Uniwersytetu Lubelskiego Jana Pawła II. Adres: Instytut Pedagogiki KUL, ul. Droga Męczenników Majdanka 70, 20-325 Lublin; e-mail: ldziaczkowska@kul.lublin.pl. 
tations/identities). Jednocześnie zwolennicy ideologii gender metodycznie negują setki badań, które wskazują na pierwotne, biologiczne zróżnicowanie mężczyzn i kobiet - jednym z najbardziej wyrazistych przykładów ignorowania ustaleń nauki przez genderystów jest film Haralda Eia pt. „Gender Equality Paradox”, którego wyemitowanie spowodowało wstrzymanie dotacji dla promowania ideologii gender przez norweski rząd. Jednocześnie obserwujemy nasilający się krytycyzm wobec tradycyjnego obrazu rodziny, oskarżanej o konserwatyzm (rozumiany pejoratywnie jako twór przestarzały i z gruntu szkodliwy) i deprecjonowanie kobiet. W tym burzliwym dyskursie pojawiło się wyraźne zapotrzebowanie na publikację, która przedstawiałaby zagadnienie różnic pomiędzy mężczyzną a kobietą w przystępny, a przy tym zgodny z aktualnymi badaniami naukowymi sposób, odnosząc się jednocześnie do krytykowanych w kręgach zlaicyzowanych wartości chrześcijańskich, zwłaszcza chrześcijańskiego modelu rodziny. Recenzowana publikacja ma szansę zaspokoić to zapotrzebowanie.

Książkę napisało małżeństwo, Barb i Walt Larimore'owie. Walt Larimore jest praktykującym lekarzem rodzinnym i nauczycielem akademickim, napisał i redagował wiele książek, jest autorem ponad 600 artykułów w czasopismach, prowadził także programy telewizyjne dotyczące zagadnień medycznych. W recenzowanej obecnie książce próbuje wraz z żoną przedstawić naukowe ustalenia dotyczące różnic pomiędzy mężczyzną a kobietą w zestawieniu z wiarą chrześcijańską. Książka została podzielona na cztery części (rozdziały). W pierwszej, zatytułowanej „Jej mózg, jego mózg. Nauka", autorzy na blisko 40 stronach opisują biologiczne różnice pomiędzy funkcjonowaniem mózgów obu płci. W tej części książki czytelnik dowie się o różnicach w strukturze mózgu męskiego i kobiecego (obejmujących m.in. układ limbiczny, zwłaszcza podwzgórze, ciało migdałowate, hipokamp oraz zakręt obręczy; różnice strukturalne zostały zestawione w osobnej tabeli na s. 52), a także o ich odmiennym składzie chemicznym (autorzy wskazują na różną ilość, a tym samym siłę oddziaływania, następujących hormonów: oksytocyny, serotoniny, estrogenu, progesteronu, testosteronu i wazopresyny). Po ukazaniu wzmiankowanych odmienności autorzy przytaczają za dr. S. Baron-Cohenem opinię, że ,pogląd, że mężczyźni są z Marsa, a kobiety z Wenus, przedstawia różnice między dwiema płciami zbyt skrajnie. Dwie płcie są różne, ale nie do tego stopnia, byśmy nie byli w stanie się porozumieć" (s. 61).

W drugiej części książki, liczącej ponad 60 stron i zatytułowanej „Jej mózg, jego mózg. Różnice”, materiał został podzielony na cztery kategorie: „Różnice w postrzeganiu świata”, „Różnice w przetwarzaniu sygnałów ze 
świata zewnętrznego”, „Różnice w komunikowaniu się ze światem” oraz „Odczytywanie różnic komunikacyjnych”. W ramach pierwszej kategorii opisano różnice $\mathrm{w}$ postrzeganiu zmysłowym, osobno rozpatrując widzenie, słuch, dotyk (w tym odczuwanie bólu) oraz węch i smak. W kategorii drugiej przybliżono czytelnikowi różnice we współodczuwaniu i w myśleniu systematyzującym, w wyobraźni przestrzennej, odmiennych reakcjach emocjonalnych (i - osobno - reakcjach na stres), a także w wielozadaniowości i w nieco kontrowersyjnej kwestii, jaką jest intuicja. Informacje z tego rozdziału zostały podsumowane tabelarycznie na s. 101. Dwa ostatnie rozdziały tej części książki to skrótowe ukazanie ogólnych różnic komunikacyjnych stanowią one dobry wstęp do kolejnej części książki.

Trzecia część książki, zatytułowana „Jej mózg, jego mózg. Wpływ na relacje", liczy aż 94 strony. Autorzy rozpoczynają tę część rozdziałem pod tytułem „Seks w wielkim mózgu”, co może wydawać się zabiegiem kontrowersyjnym, gdyż relacje nie wszystkim kojarzyć się muszą w pierwszej kolejności właśnie z seksem. Lektura rozdziałów zamieszczonych w tej części książki zasadniczo rozwiewa te wątpliwości. Nawiązując do wcześniej przedstawionych treści, Walt i Barb Larimore udowadniają, że to mózg jest narządem, który spośród wszystkich innych jest najbardziej odpowiedzialny za szeroko rozumiany seks. Sprawia to, że różnice pomiędzy mężczyzną a kobietą powodują, iż w związku małżeńskim dochodzi do wzajemnego uzupełniania się, do wzajemnego uczenia się miłości, co do której akcenty w przypadku obu płci są nieco inaczej rozłożone. Agresja i potrzeba szacunku, chęć walki i dowiedzenia swojej wartości, spotyka się z opiekuńczością i potrzebą miłości, czułością i emocjonalnością. Ta część książki stanowi reprezentatywny przegląd aktualnych trendów w literaturze dotyczącej różnic komunikacyjnych pomiędzy płciami, czytelnik będzie miał okazję przeczytać, chociażby bardzo skrótowo, o poglądach takich autorów jak John Eldredge, Shaunti Feldhahn, Emerson Eggerichs, Anne Moir, David Jessel i wielu innych, co jest niezaprzeczalnym atutem książki. Nawet ci, którzy nie mieli do czynienia z pracami wymienionych tu osób, za pośrednictwem recenzowanej książki będą orientować się w miarę dobrze w aktualnej tematyce relacyjnej. Oczywiście brak tu naszych rodzimych autorów, których dzieła zdecydowanie warte są poznania (wymieńmy chociażby Jacka Pulikowskiego, Wandę Pułtawską, Michała Piekarę czy cały szereg audycji ks. Piotra Pawlukiewicza), ale nie wpływa to na pozytywny odbiór książki.

Ostatnia część recenzowanej publikacji nosi tytuł „Jej mózg, jego mózg. Piękno Bożego projektu". Składają się na nią dwa rozdziały, które łącznie obejmują niespełna 22 strony tekstu. Autorzy w tej części dokonują refleksji 
nad tekstem biblijnym, głównie nad opowiadaniem o stworzeniu człowieka z Rdz 2. Z uznaniem należy ocenić zarówno wybór, jak i omówienie wersetów biblijnych, czego wymownym przykładem jest interpretacja greckiego słowa asthenēs z 1 P 3, 7, które jest użyte na określenie „słabszego ciała kobiecego" (BT).

Podsumowując, recenzowana publikacja stanowi bardzo wartościowe źródło informacji dla tych wszystkich, którzy chcieliby poznać rzeczywiste, udowodnione naukowo różnice pomiędzy męskim i żeńskim mózgiem, a przy tym osadzić tę wiedzę w perspektywie dojrzałej wiary i dochodzenia do jak najlepszej komunikacji w małżeństwie.

Krzysztof Pilarz*

\section{Grzegorz Godawa, Funkcjonowanie rodziny dziecka objętego domowa opieka hospicyjna. Studium tanatopedagogiczne, Toruń: Wydawnictwo Edukacyjne Akapit, 2016, s. 452.}

DOI: http://dx.doi.org/10.12775/PCh.2017.019

Grzegorz Godawa jest znanym autorem, zwłaszcza w gronie osób interesujących się pedagogiką chrześcijańską. Jego twórczość naukowa koncentruje się w kilku kręgach tematycznych, takich jak: pedagogiczne konteksty wsparcia dla rodziny, problematyka kształcenia i wychowania uczniów oraz przygotowania nauczycieli do pracy dydaktycznej, rola mediów w rozwoju dzieci i młodzieży, wybrane zagadnienia pedagogiki chrześcijańskiej. Najbardziej rozwinięta i zaawansowana jest jednak ta część twórczości Grzegorza Godawy, która odnosi się do problematyki tanatyczno-hospicyjnej. $\mathrm{W}$ istotnym stopniu opiera się ona na wieloletniej pracy duszpasterskiej oraz opiekuńczej Autora w hospicjach domowych, w których znajdują się dzieci terminalnie chore.

W swoim dorobku Grzegorz Godawa ma 15 opracowań, w których podejmował takie zagadnienia, jak: działalność hospicjów dziecięcych w kon-

* Dr Krzysztof Pilarz jest adiunktem w Wydziale Teologicznym Uniwersytetu Mikołaja Kopernika w Toruniu, w Katedrze Pedagogiki, Katolickiej Nauki Społecznej i Prawa Kanonicznego. Adres: Wydział Teologiczny UMK, ul. Gagarina 37, 87-100 Toruń; e-mail: pilarz@, umk.pl. 